\title{
Rh Factor
}

National Cancer Institute

\section{Source}

National Cancer Institute. Rh Factor. NCI Thesaurus. Code C67517.

A family of 45 different antigens on the surface of red cells that are controlled by 2 closely linked genes on chromosome 1. 